\title{
OH PHILOSOPHY! THERE WILL BE NO MORE SORROW OR FORGETFULNESS. A REPLY TO CARLOS MONTEMAYOR'S "RATIONALITY AND REASONABLENESS IN LEGAL THEORY”*
}

\author{
¡OH, FILOSOFÍA! NO HABRÁ MÁS PENA U OLVIDO. RÉPLICA A "RATIONALITY
}

AND REASONABLENESS IN LEGAL THEORY” DE CARLOS MONTEMAYOR

\section{Guillermo LARIGUET**}

* Artículo recibido el 23 de marzo de 2014 y aceptado para su publicación el 10 de agosto de 2014.

Many of my claims in this article are based on the following works, some of them unpublished. For methodological questions regarding how to conceive the normative task of the philosophy of law and the doctrine drawn up by jurists, I have used my unpublished article "Señor, iyo soy un dogmático!...pero jurídico" (Sir, I am a dogmatist, but a legal one!). A more thorough criticism of methodological legal positivism can be found in "Analytical Legal Philosophy Reloaded", published in Problema 8 (2014); this paper is also complemented by the work "El aguijon de Aristófanes y la moralidad de los jueces" (Aristophanes's sting and the morality of judges), Doxa. Cuadernos de Filosofia del Derecho, No. 36, Alicante (in press). The topic of conceptual analysis and weak naturalism can be found in a text, submitted to a philosophical journal for evaluation, which I have entitled "Ética, giro experimentalista y naturalismo débil" (Ethics, the experimentalist turn and weak naturalism), discussed in part at the Conference of Epistemology and History of the School of Philosophy of the National University of Cordoba, in 2012-2013. My ideas on a reformulation of conceptual analysis in combination with a certain weak form of naturalism can be found in the text "Filosofia Práctica Impura y Normativa" (Impure and Normative Practical Philosophy) which I discussed at the International Conference of Practical Philosophy organized by the Universidad de Ciencias Empresariales y Sociales of Buenos Aires in 2013. Lastly, my ideas on the importance of literature as a support vehicle for philosophical knowledge can be found in "El valle fértil de la literatura y sus frutos para la filosofia moral" (The fertile valley of literature and its fruits for moral philosophy), discussed in the Colloquy on the Ethics of Discourse, Rio Cuarto (currently in press), both events held in Argentina.

I thank to Dr. René González de la Vega for his conceptual criticism of a former version of this work. Additionaly, I want to thank Sandra Gómora, Enrique Rodríguez, Juan Vega and Nicholas Basily for their helpful suggestions in order to improve the style of this paper.

** Researcher for the Council of Scientific and Technical Research of Argentina (CONICET in its Spanish acronym), Center for Legal and Social Research, National University of Cordoba, gclariguet@gmail.com. 


\title{
GUILLERMO LARIGUET
}

\section{Resumen:}

En este artículo doy respuesta a los comentarios de Carlos Montemayor en su colaboración "Racionalidad y Razonabilidad en la Teoría Jurídica". Mi argumento es que en la filosofia en general - pero también en la filosofia jurídica en particular - existe cierta forma de entender el enfoque analítico que genera un aislamiento teórico sujeto a críticas, las cuales pretendo desarrollar en el trabajo. Asimismo, explico la forma en que la frase "filosofia jurídica recargada" que utilizo en mi trabajo es una de contenido normativo. Por último, distingo dos versiones de naturalismo y argumento a favor de una versión débil en el contexto de defender el análisis conceptual.

\section{Palabras clave:}

Filosofia analítica, metodología de la filosofia del derecho, normativismo, naturalismo, diálogo entre tradiciones, puentes entre disciplinas.

\begin{abstract}
:
In this paper I reply to Carlos Montemayor's Rationality And Reasonableness In Legal Theory. My claim is that in philosophy in general -but also in legal philosophy in particular- there is a certain manner of understanding the analytical approach that reproduces a theoretical isolation which I find open to criticism for the many reasons I outline in the text. Additionally, I explain the way in which the phrase "legal philosophy reloaded" used in a recent article of mine is a normative one. I then distinguish between two versions of naturalism and claim for a weak version in the context of a defense of conceptual analysis.
\end{abstract}

Keywords:

Analytical philosophy, Jurisprudential Methodology, Normativism, Naturalism, Dialog between Traditions, Bridges among Disciplines. 
1. I am warmly grateful to Carlos Montemayor for his reply to my paper "Analytical Legal Philosophy Reloaded". I may be stating the obvious by saying that for one philosopher to enter into discussion with another is a matter of great joy. A reply from an interlocutor as intelligent as Montemayor encourages one to double the effort and think over the issues in greater clarity and depth. This is perhaps what the vision of philosophy as a cooperative undertaking rests upon. And this undertaking requires one to deploy, albeit not always successfully, virtues such as patience to assimilate complex ideas and embody them suitably, humility to admit error, courage to defend personal theoretical perspectives and persistent doubts.

2. "Analytical Legal Philosophy Reloaded", the target of Montemayor's constructive criticism, is relatively long. Therefore, and because it was published in Problema. Anuario de Filosofía y Teoría del Derecho, issue 8 (2014), I shall not develop what I expounded there. Rather, I shall expand upon some of the arguments therein in order to construct a conceptually clearer basis of the kind of purposes that serve to guide me.

3. If I had to summarize one of the purposes in my paper, I would say that I am "personally fed up" with a certain manner of teaching and practicing philosophy in general and legal philosophy in particular. This feeling could initially be overcome by identifying what I consider to be deplorable attitudes of philosophers in general and of legal philosophers in particular. Secondly, I identify areas of "forgetfulness" in philosophy in general and in legal philosophy in particular. Hence, and paraphrasing Argentine writer Osvaldo Soriano, the motto of this paper might be: Oh, Philosophy! There will be no more sorrow or forgetfulness.

4. To make my point simpler, I shall understand sorrows and forgetfulness to be two sides of the same coin. First of all, when I talk of "philosophy" in general and "legal" philosophy in particular I am taking into consideration one relatively specific kind of style: what is known as analytical phi- 


\section{GUILLERMO LARIGUET}

losophy. If I state that some analytical philosophers have constructed philosophical works that combine sorrow and forgetfulness, this seems to place me outside this style or tradition. Far from it: I feel I am part of the analytical tradition; it's just that I deplore certain forms of articulating, teaching and re-producing it. This feeling comes from many cases I know both sufficiently and directly. I shall not, however, give names: each of us should accept a share of the blame.

5. In "Analytical Legal Philosophy Reloaded" I proposed, as a coda, norms I believe could pull philosophy out of this quagmire of sorrow and forgetfulness. Firstly we find the deplorable attitude underlying certain forms of developing conceptual analysis. In my opinion, this attitude ties in with the strong isolation of the analytical tradition, particularly of many of its representatives, with regard to other traditions. It seems that the mere mention of names like Hegel, Kierkegaard or Nietzsche makes their hair stand on end. This becomes more conspicuous in the case of the so-called "legal philosophers". By this label I refer fundamentally to all those jurists who took philosophical tools, from here and there, to inquire into conceptual issues related, generally exclusively, to law. I say "generally" because, except for some specific and intermittent instances, it is very unusual to find a legal philosopher writing about other philosophical problems. This is not the case of philosophers in general. One may find McDowell writing on Ethics, the theory of knowledge, philosophy of mind. Ruth Marcus doing work on Ethics or Logic, Habermas on religion, law, epistemology, etc. And the list could go on and on. This observation, I believe, says something about the predominant training received by jurists who will devote themselves to philosophy. Although Montemayor does not dwell on this point, I would say it is an essential part of the work he remarks upon. There is a certain link here between, on one hand, the manner of receiving and teaching philosophy in the legal world and, on the other, poor con- 
ceptions of philosophy of law such as those defended by methodological positivists. I mean "poor" on account of their scant attention to the broader environment of practical philosophy.

6. What is more, I would say that the reception jurists have made of general philosophy, particularly of the broad, varied analytical tradition, has been awkward and shallow when they develop "their" own legal analytical style. Part of this regrettable awkwardness resulted from a lack of sensitivity to the conceptual history of philosophy and from forgetting that we are philosophers before becoming "analytical" philosophers and "legal" philosophers.

7. The awkwardness and lack of sensitivity I have mentioned has relegated important details of philosophy in general and its evolution to oblivion, as well as those of the complex history of the analytical movement. For example, it has frequently led us to forget that: a) the movement known as "logical positivism" can only be understood as a challenge and dialog with neo-Kantian traditions; b) Bertrand Russell's atomism cannot be understood without a criticism Russell leveled against the British Hegelian tradition; c) Wittgenstein never managed to free himself from Williams James's The Varieties of Religious Experience: A Study in $\mathrm{Hu}$ man Nature, and read Kierkegaard's Fear and Trembling; d) Bernard Williams claimed that, in nuce, a type of analytical methodology is to be found in the Nietzschean conceptual genealogy; e) Hilary Putnam seriously discussed Derrida or Foucault's thesis; f) Husserl's phenomenological method is an important part for the anti-psychologistic shift undergone by analytical philosophy with Frege when facing the logical nature of concepts and propositions. A long etcetera may be added to this list.

8. This suggests that, qua philosophers, only ill-advised pedantry could lead us to "forget" philosophers of other traditions which are necessary to understand the development of our own analytical philosophy. We cannot hurriedly and haughtily claim that other traditions have nothing to say or 


\section{GUILLERMO LARIGUET}

that what they do say is simply unintelligible. Some may find it hard to understand the Heideggerian dasein or Hegel's idea of an objective spirit. But I can't help wondering: do we take it for granted that someone from another tradition will immediately understand a plethora of terms such as qualia, memes, propositional attitudes and the dicto/re distinctions, definite descriptions, etcetera? Of course, it is commonplace to claim that the evaluation criteria for achieving excellence in analytical philosophy are more rigorous than in other traditions. I shall put this thesis in doubt here. What I shall point out, is that there is no abundance of definitions of "rigor". Nor is there a serious study by experts of what the criteria are for judging philosophical research to reach middling success in another tradition. But if we consider the (wrongly dubbed) continental tradition, it is almost certain that sensitivity for the historical context of problems, along with the need not to display conceptual distinctions simply as part of a frivolous, vain game, serve as criteria for assessing a paper's philosophical excellence or meagerness. Sometimes we analytics exasperate under the demand for clarity and this can be claimed to be the unparalleled condition of our own work. But as far as I know, many philosophers who do not claim to be analytical are, at least to me, extraordinarily clear, while there are philosophers labeled as analytical who are at times surprisingly obscure. It is also claimed that we analytical philosophers distinguish concepts and this is proper to our own method. Yet again, this is a hasty claim. If, for example, one reads a philosopher interested in distinguishing categories such as "temperament" with regard to "feelings", by comparing theories like those of Scheler or Kierkegaard, one will doubtless find a precise, appropriate interplay of distinctions necessary to clarify a relevant difference. It is not a question of making an impression of being a sophisticated philosopher, but rather of clarifying topics and relevant differences. 
9. The kind of regrettable awkwardness and forgetfulness I am considering refers to a feature extensible to many analytical philosophers, but especially to those jurists who have decided to devote themselves professionally to philosophy, studying a little of this, a little of that, fragmentarily and ad hoc, almost exclusively in order to elucidate problems of law. In general, this paucity of intellectual training of jurists combines with an obsession for endlessly investigating the same issues, much like a favorite fetish. For example: "Let's talk about legal positivism for the millionth time because it's still not clear!". Also the cultism (sometimes "occultism") of making multiple distinctions, the purpose of which is only a presumed analytical finesse. Perhaps some legal theorists show this kind of zeal when they say, for example, that they will distinguish between the meanings of a long list of expressions such as "legal interpretation" or "value pluralism", as would be the case of authors like Guastini or Barberis. I am not saying there is no need to distinguish: I am saying that distinctions are legitimate in the context of purposes more complex than merely showing off a purported analytical finesse. We distinguish in order to "clarify" an issue; but we clarify based on issues or differences we judge to be relevant, at least presumably. I say "presumably" relevant because legal-philosophy jurists often work in such a markedly isolated manner that they tend to develop an exaggerated belief in the importance of their problem within the global context of philosophical knowledge.

10. On the other hand, it is striking how legal philosophers, whose professional training is as "jurists", operate in a "borderline" manner. They are philosophers when it suits them, mainly when they address civil law professors, for example: attorneys or judges. But when they speak to "philosophers", they often say: Don't forget we're jurists! Let's not get involved in topics we're not trained in! Let's leave them to philosophers! So where does this leave us? This attitude seems deplorable to me and could well lead jurists to forget 


\section{GUILLERMO LARIGUET}

all they owe to actual philosophers. Hence the inclusion of the quotation of Hobbes from Dialog between a philosopher and a jurist. ${ }^{11}$

12. Lastly, there is an additional regrettable awkwardness that has to do with a lack of attention to the important problem of "style". There is no such thing as a "single" uniform analytical style. Let us compare, for example, the style of the second Wittgenstein with that of Donald Davidson, Thomas Nagel, Bernard Williams, Martha Nussbaum, Joseph Raz, Stanley Cavell, Daniel Dennett, Alvin Plantinga or Korsgaard and we shall observe an interesting palette of shades and differences. Or, for that matter, let us examine closely how philosophers like Eugenio Bulygin, Carlos Nino, Eduardo Rabossi, Ricardo Caracciolo, Fernando Atria, Daniel Kalpokas, Fabián Mie, René González de la Vega, Claudio Michelon, Federico Marulanda, Pablo Navarro, Juan Vega, Mark Platts, Laura Danón, Gonzalo Rodríguez Pereyra, Gustavo Ortiz Millán, Carlos Pereda or Hugo Seleme write. From this list, which serves as a mere example, all of them, in a narrower or broader sense, can be claimed to be analytical. But they do not share exactly the same idea of analysis nor the same style in their writings.

13. The style has to do with the methodological question of "how to express our ideas": the how and what are inseparable and there are sometimes horrendous examples of an analytical style that is so exacerbated that it ends up becoming a caricature of philosophy. For example, Carlyle's sartor resartus ,' philosophical attire in which ideas appear ragged or deformed. In my opinion, it is not a question of "first let's get it right, then let's give it style." Doing philosophy well and giving it style for me are inseparable. And, in recent years, I am tempted to think that a deeper knowl-

1 Or "The tailor re-tailored". Through the character of Diogenes Teufelsdröckh, Carlyle mocks Hegelianism. He shows how wearing poorly designed garments can make one look "deformed". In my opinion, "falling for Sartor Resartus" is equivalent to being deformed in the "Procrustean bed". That is to say, the caricature of deformation of ideas or concepts. 
edge of the humanities (particularly literature 2 ) and of the achievements and failures of science can provide us with interesting lessons in order to develop a style that is able to amalgamate beauty and clarity, accuracy and imagination.

14. These points serve as a preliminary to answer one of the concerns in Montemayor's reply. Although I limited the title to "legal" "analytical" philosophy reloaded, and placed it directly in relation to what I called "practical philosophy", my diagnosis extends to philosophy in general. 3 I think philosophers have become so specialized that they no longer master "disciplines" but rather specific topics. I am not claiming that we should not master an area of topics and disciplines; but it does not follow that we should give up on developing an ongoing vocation for a general view of philosophical problems. I have realized that virtually all the great philosophical problems can be likened to rivers replicated in different disciplines and under different theories. But the same problems appear under different names; hence, having a global vision of philosophy provides us with a more powerful vision of the problems, less parochial from the point of view of disciplines taken insularly. Hence my quotations of Ortega y Gasset and Magris in Analytical Legal Philosophy Reloaded. In this sense, I share with MacIntyre the diagnosis he makes in God, Philosophies, Universities, that uni-versities have often become multi-versities. ${ }^{4}$ We have lost sight of the importance of erecting bridges between problems, concepts, theories and disciplines. This is why I think it is urgent, particularly in the so-called legal philosophy, to once again reflect upon the methodological

${ }^{2}$ In fact, my current prevalent research is on literature as an instrument of philosophical knowledge.

3 By the way, although Carlos proposes the need for philosophy as a global undertaking to be "reloaded", he titles his work Rationality and Reasonableness in Legal Theory" (the latter underscored in his work).

${ }^{4}$ Outside of Catholic universities, I do not share MacIntyre's view that the presupposition of God is necessarily required in order to think of a unity of knowledge. 
and substantial effect of serious, calm reflection on terms like "intertheory", "interdiscipline" and "transdiscipline". To confirm, at least partially, what I am pointing out, let me give a real testimony from my immediate surroundings; this is a background that could well be extended to many other Latin American and European universities. The School of Law of the National University of Cordoba is but a few blocks from the School of Philosophy. However, rarely and only exceptionally and dispersedly, do legal philosophers walk those few blocks to talk to philosophers or other humanists. Rarely too, it must be said, do philosophers show any interest in what is being done at the School of Law. There is a mix of disdain and prejudice, justified at times, which accounts for why philosophers are hardly willing to walk those few blocks and become interested in what jurists are doing.

15. After this propaedeutic, let us consider Carlos Montemayor's main claims. These are, initially, "methodological". Secondly, they are aimed at renewing not just the landscape of legal philosophy but also that of philosophy as a global undertaking. Lastly, Montemayor proposes a distinction between two senses of the expression "reloaded", thus suggesting a vague or ambiguous usage in my text. These two senses are, in broad terms, a "naturalist" one which he links to the term "rationality" and another "normative", linked to the term "reasonableness", understood in the terms of Jürgen Habermas. What Montemayor does not clarify, however, is why "rational" appears to be restricted to the instrumental and does not reach a discussion of ends, for example of those of a scientific investigation involving human beings. Nor is it clear to me whether reasonableness is, for him, an evaluative criterion of some kind of ethical and political dimension that the natural sciences ought to satisfy. To be fair, I must point out that I do coincide with Carlos's general intuition: the normative concept of reasonableness applied to human sciences obliges one to take as a basic supposition the idea that there are many 
normative questions (of the sort: "we ought to do x", "are these desires normatively acceptable?" or "x often happens, but is it good to facilitate it?") which are not reducible to completely natural bases. We can admit some naturalist bases of normative knowledge, but this does not mean we must forgo normative presuppositions. Authors such as Korsgaard are to be found in this line of thought and I too feel close to it.

16. Carlos is right in pointing out that the basic concerns in my text may be rendered as "methodological". I say "may" because obsessions in my work are also substantial: I worry about the relationship that can be established between the law and its nearest neighbors: morality and politics, as well as neighbors who "are just round the corner" like philosophy of mind or the theory of knowledge.

17. Primarily, I must define the meaning of the term "methodological". By "methodological" I do not understand something in the style of "cooking recipes" like those provided by self-dubbed "legal methodologists". These "methodologists" sometimes exhibit the rare talent for frustrating good research projects which are usually done by "doctrinarians" of law and, secondly, philosophers, sociologists and lastly legal historians. These "methodologists" are used to enthroning their method as though it were a universal recipe book. This is deplorable because "their" method is but a restricted theoretical version of a certain useful recipe book of limited ends. However, these methodologists behave like "podiatrists". Instead of clipping nails, they clip the wings of my students' imaginations. And "imagination" is a fundamental heuristic tool for any philosopher and for any scientist! From the imperiousness of "their" method, these professors determine whether "You -legal doctrinarian or legal philosopher - can do this or you can do that." No. As to "methodological" issues, Carlos and I appear to understand the same thing: the philosophical discussion of different problems we face when trying to "know" something: be it law, the mind, morality, etcetera. 


\section{GUILLERMO LARIGUET}

18. But the problems do not only overwhelm the self-dubbed legal methodologists. A number of philosophers in my country regrettably continue to claim, for example, and without the slightest theoretical misgiving, that the value judgments in a Constitution are simply purely subjective projections. ${ }^{5}$ In addition, they hold the idea according to which "scientific" task, that is distinctive of legal science, is reducible to the activity of "describe" the law, and so on" I have also heard theorists like Ricardo Guibourg say that analytical legal philosophy rejects metaphysics. This is just perplexing. It overlooks the multiple efforts of profound analytical philosophers to unfold a descriptive (as in the case of Strawson) or revisionist (as is the case of Parfit) metaphysics. In fact, analytical philosophers have been working for years on metaphysical categories that operate as indispensable conceptual strata in operations of individuation, attribution of properties, exercising predication, etcetera, in

${ }^{5}$ For example, I have personally heard positivist authors like Bulygin claim that objectivism obliges us to accept that value judgments require a basis of "normative facts". Bulygin does not normally provide a conceptual argument to reject this thesis; he does not explain what types of facts he questions, whether in a naturalist of non naturalist version; he is content to claim, toto genere, that such facts do not exist. But even though this were philosophically provable, other possible senses of objectivity would remain. Let us say briefly that it is possible to think that to defend a position of value requires us to provide arguments. To say that reasons are impossible in matters of value itself requires reasons. The task of providing reasons presupposes the methodological need to use a parameter of objectivity as regards "argumentability". In philosophy we have many instruments for assessing good and bad arguments.

6 This is most doubtful. In my opinion, doctrinarians of law have a predominantly practical or normative purpose. Description may be possible, but it is at the service of deploying multiple normative activities geared towards improving practices, auxiliary to law operators, etcetera. If this deserves to be called "science" does not seem to me to be all that relevant. Rather, we should be discussing whether it involves some kind of "knowledge" that is rationally communicable and discussable, and socially useful. 
areas such as the philosophy of physics (regarding notions of space and color), of mind (notions of qualia), and in moral philosophy (notion of person). As I have pointed out, I would like to claim that there has been many developments in the field that would oblige one to clarify, if not deny, statements of this sort.

19. I agree with Carlos when he proposes re-invigorating philosophy in general and not just legal philosophy in particular. This fact is what lies at the heart of my work Analytical Legal Philosophy Reloaded. Although it focused mainly on "legal" philosophy, not for a second did I think the discussion concerning its status (a typical methodological question in Carlos's terms and in mine) could be transported to philosophy in general. Hence my explanation of Sellars's idea of a "global intellectual landscape." We are interested in the landscape considered globally, just as we are interested in the place legal philosophy should fruitfully occupy within this landscape.

20. I must add that it is clear to me that philosophy departments, with a few exceptions, do not much care for legal philosophy, unlike what some legal philosophers naively suppose. This is unfortunate because, as I have claimed in my article, many valuable things are to be learned philosophically speaking from the law (hence the quotations from Popper, Mackie, etcetera, in the text criticized by Montemayor).

21. The distinction Carlos then proposes between two senses of the expression "reloaded" seems pertinent to me, though non-exhaustive. I must, however, firmly deny the suggestion of ambiguity in how I use the term. Firstly, there is no need to use a charitable strategy, it seems to me, to discard, at least in my text, the naturalist sense proposed by Carlos. This will soon become evident. But, to begin with, I must admit that the notorious sense of Analytical Legal Philosophy Reloaded is, above all else and quite explicitly, "normative" and is familiar, though, it is not fully sympathetic to the ideas conveyed by Ronald Dworkin over 


\section{GUILLERMO LARIGUET}

many years. Indeed, the philosophy of law, from my point of view, is more relevant insofar as it becomes self-aware that its most prominent role is normative. This need for self-awareness is boosted when we embark upon the broadest tradition of philosophy: from Aristotle and Plato who saw lines of continuity between metaphysics and moral theory. Or a tradition proper to Kantians claiming that what is valid in theory must be valid in practice. Why not recall Leibniz's motto theoria cum praxi? Even Dewey's pragmatic idea that philosophers, for example, should discuss the problems of the people, and that all theoretical tasks have practical ends, making our different social practices more intelligent — more reasonable Montemayor would say- My claim does not imply a denial of the descriptive task. Rather, it indicates that we are not content simply to observe the spectacle of the world, as Ricardo Reiss de Pessoa used to say. Our most vigorous purposes are normative 7 and fit in, ultimately, with proposing how the law can have authority. This means forsaking the ideal of "value-neutrality" but does not free us from the no less demanding ideal of being intellectually honest.

22. What I am suggesting does not involve confusing descriptive and normative tasks, normally adduced. This means that by testing our intuitions we realize that our hard conception consists of the fact that the law "should" be able to align itself with morality as a whole and under the best possible version of political design. This involves the arduous epistemic task and responsibility of putting out the best possible interpretation of law as a complex con-

7 When I defend a normative task for legal philosophy, my defense does not take for granted that I fall for the type of theoretical isolation I criticize in this article. It is necessary to distinguish the ends I consider predominant for the legal philosopher and which demand a considerable effort of self-awareness, of the utterly different fact that philosophical work, training and teaching must embrace, within the minds of university students, professors and researchers, i.e. A well-oiled form of communication among philosophical and non-philosophical disciplines. 
struct, after long, reasonable philosophical exchanges and misunderstandings.

23. When I say that my contention is not totally Dworkinian it is because I allow myself - perhaps in terms of assuming risks - to combine a normative approach with what I call the state of alert or suspicion regarding the aspects of the law that I shall here call "ideological" in a deliberately broad sense. Legal philosophy may be normative but it is not naive: it must therefore show a deep concern for the ideological machinery underlying the creation, interpretation and teaching of law.

24. The topic of naturalism invoked by Montemayor deserves a special place. This is a term that is used in at least two different senses: one strong and one weak. In order to simplify my presentation, let it suffice to say the following here: the first sense basically implies that philosophy may be completely substituted by methods from the natural sciences. The second implies, on the other hand, that the methods of the natural sciences should be auxiliary to the task of conceptual analysis. I am a defender of bridges among disciplines. However, I am doubtful about the possibility, or even the intelligibility, of a strong naturalistic project. This is because I believe we always need to analyze concepts. Even a materialist in the philosophy of mind should have to explain what the heck it means to say "a brain thinks." The scientist would doubtless be able to explain the material bases of the brain; but a good conceptual analyst - a condition the scientist does not always attaincould say that the phrase "the brain thinks" is simply unintelligible. It is the "brain" that thinks: we therefore need a good theory of mind. And if this theory were explicable in materialist terms, we would still need the philosopher and the conceptual analyst. Mutatis mutandis, something similar happens with religion. A self-confessed naturalist like Daniel Dennett can attempt to "break the spell," showing the biological and psychological evolutionary bases that explain the emergence and maintenance of religions; but this does 
not mean that Dennet has utterly abandoned conceptual analysis. In fact, he analyzes the concepts of God, belief, religion or meme in terms of his indispensable philosophical clarification.

25. It is true that the philosopher can sometimes risk natural-scientific hypotheses. But this does not mean she has quit being a philosopher: we must assess the epistemic credibility of her hypothesis on a scientific basis. And we may discover that the philosopher is a very poor scientist. After all, even philosophers have sometimes spoken of sublunar worlds or supported the thesis of the "phlogiston" which falsely attempted to explain combustion. I believe a sensible philosophical reflection may requires a weak naturalism. This is compatible with of Habermas who, in my opinion, admits a weak version of naturalism. For example, if one is interested in ethics, one cannot dispense with neuroscientific studies about what triggers a compassionate action or what cerebral mechanisms are activated when observing one person physically harming another. What is more, a normative ethicist needs natural instruments to be able to establish the "empirically viable" or "empirically possible" nature of her theory. Therefore certain aspects of philosophical theories may be molded or readjusted by empirical data. For instance, I think this is what underlies Rawls's attempt to make his theory of justice "stable" over time. What should be readjusted, then, are the theories' conditions of possibility, be they moral or political theories, of the mind and of knowledge referring to perception and the interplay of conceptual and non-conceptual content (Mc Dowell-Evans dispute), etcetera.

26. I hope my clarification responds, at least in part, the questions posed by Montemayor. There is no doubt that I owe a more elaborate reply on how I see conceptual analysis in general insofar as it is a complex set of intellectual operations on concepts. This will also call for the articulation of a theory of concepts. And such a theory requires a dialog between logic, epistemology, philosophy of mind, et- 
cetera. Also pending is a discussion of the problematic relationship between apriority and the historical dimension of our concepts.

27. Finally, some of my claims may be regarded as unfair for legal analytical philosophers and jurists. There will doubtless be exceptions, even honorable exceptions among them. But when I talk of sorrow and forgetfulness, I talk of a zeitgeist, a certain trend in which many might recognize themselves, this is my main target and the one I criticize. As for me, I hope that there will be no more sorrow and forgetfulness for the philosophy I portray here.

\section{BIBLIOGRAPHY}

LARIGUET, G., 'El aguijón de Aristófanes y la moralidad de los jueces' (2013) 36 Doxa. Cuadernos de Filosofía del Derecho 107.

_- 'Analytical Legal Philosophy Reloaded' (2014) 8 Problema. Anuario de Filosofía y Teoría del Derecho 3.

MONTEMAYOR, C., 'Rationality and Reasonableness in Legal Theory', (2014) 8 Problema. Anuario de Filosofía y Teoría del Derecho 39. 